\title{
Studies on foliicolous fungi - XXVII
}

\section{B. Hosagoudar and G. R. Archana}

Abstract: Two new species, namely, Asterina flexuosae vel anfractuae, opposite, alternate vel psychotriicola on Psychotria sp. and Lembosia salaciae irregulariter acuteque vel laxe ramosae, laxe vel dense on Salacia sp. collected from the Western Ghats of reticulatae, cellulae 16-32 x 4-8 $\mu \mathrm{m}$. Appressoria pauca, Peninsular India are described and illustrated in detail. $\quad$ bicellula, unilateralis vel alternata, recta vel curvula, 9-18

Keywords: Asterina, Lembosia, new

species, Western Ghats, India

Asterina psychotriicola sp. nov. (Fig.1)

Coloniae epiphyllae, subdensae vel densae, ad $3 \mathrm{~mm}$ diam., saepe confluentes. Hyphae flexuosae, irregulariter acuteque vel laxe ramosae, formans laxe rete, cellulae 9-35 x 3-5 $\mu \mathrm{m}$. Appressoria ovata, clavata, leniter stipitata, unicellularis, ad apicem attenuatae et late rotundatae, integrae, 8-13 x 6-10 $\mu \mathrm{m}$. Thyriothecia dispersa, orbicularis, ad $400 \mu \mathrm{m}$ diam., stellatim dehiscentes ad centro, margine plerumque crenatae; asci globosi, octospori, ad $30 \mu \mathrm{m}$ diam.; ascosporae oblongae, brunneae, conglobatae, uniseptatae, constrictae ad septatae, 20-24 x 9-13 $\mu \mathrm{m}$, parietus fortiter tuberculatus.

Colonies epiphyllous, subdense to

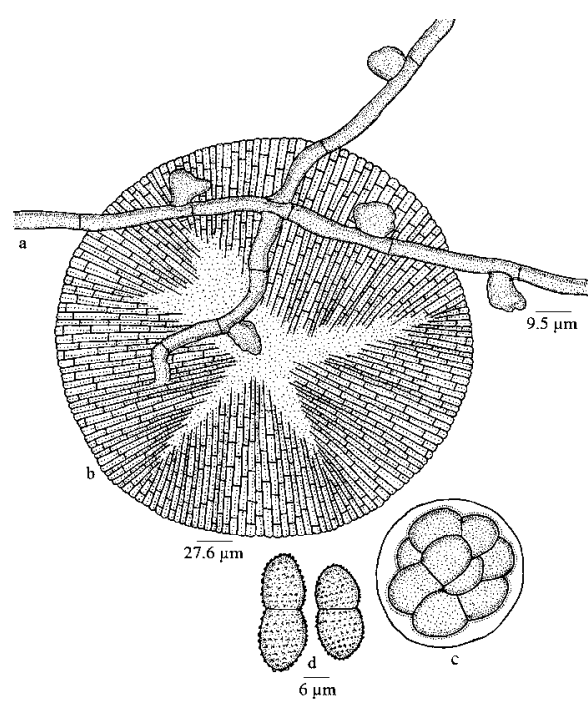

Fig.1. Asterina psychotriicola sp. nov. a- Appressoriate mycelium, b-Thyriothecium, c- Ascus, d-Ascospores $\mu \mathrm{m}$ longa; cellulae basilares cylindraceae vel cuneatae, 3-6 $\mu \mathrm{m}$ longae; cellulae apicales ovatae, oblongae, rectae, curvulae, integrae vel leniter angularis, 4-11 x 4-10 $\mu \mathrm{m}$. Thyriothecia dispersa vel aggregata, ad initio orbicularis, elongata ad maturitata, 500-640 x 250-300 $\mu \mathrm{m}$ diam., dehiscentes longitudinalis ad centro, margine crenatae vel fimbriatae; hyphae fringiorum flexuosae vel anfractuae; asci globosi vel ovati, octospori, 32-42 x 26-35 $\mu \mathrm{m}$.; ascosporae ovatae, oblongae, brunneae, conglobatae, uniseptatae, constrictae ad septatae, 28-35 x 12-18 $\mu \mathrm{m}$, parietus glabrus.

Colonies amphigenous, subdense, up to $2 \mathrm{~mm}$ in diameter, confluent. Hyphae profusely branched, flexuous to crooked, dense, up to $3 \mathrm{~mm}$ in diameter, often confluent. Hyphae branching opposite, alternate to irregular at acute to wide flexuous, branching irregular at acute to wide angles, form a loose net, cells 9-35 x 3-5 $\mu \mathrm{m}$. Appressoria ovate, clavate, slightly stipitate, unicellular, attenuated and broadly rounded at the apex, entire, 8-13 x 6-10 $\mu \mathrm{m}$. Thyriothecia scattered, orbicular, up to $400 \mu \mathrm{m}$ in diameter, stellately dehisced at the centre, margin mostly crenate; asci globose, octosporous, up to $30 \mu \mathrm{m}$ in diameter; ascospores oblong, brown, conglobate, uniseptate, constricted at the septum, 20-24 x 9-13 $\mu \mathrm{m}$, wall strongly tubercled.

Material examined: On leaves of Psychotria sp. (Rubiaceae), Kukke Subramanya, South Canara, Mangalore, Karnataka, India, Nov. 15, 2003, V.B.Hosagoudar \& al HClO 46689 (type), TBGT 2030 (isotype).

Asterina psychotriae Ryan is known on this host genus from Puerto Rico (Stevens \& Ryan, 1939). A. psychotiicola differs from it in having longer appressoria and ascospores.

Lembosia salaciae sp. nov. (Fig.2) Coloniae amphigenae,

subdensae, ad $2 \mathrm{~mm}$ diam., confluentes. Hyphae libero ramosae,

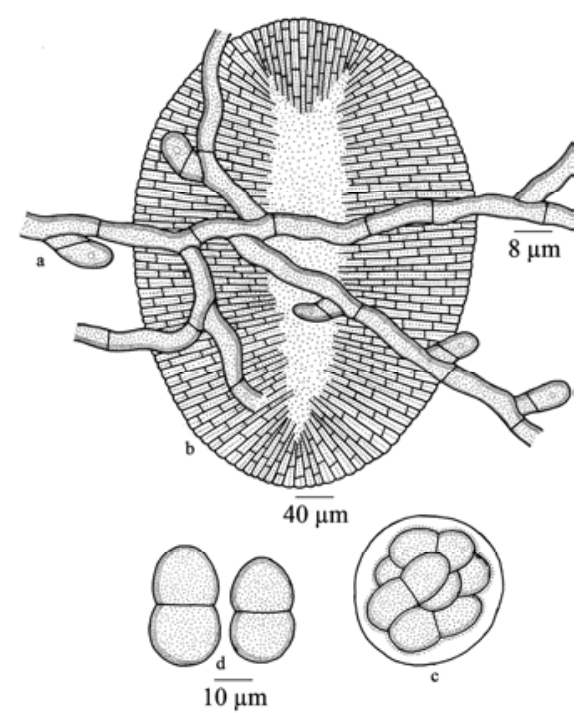

Fig.2. Lembosia salciae sp. nov. a- Appressoriate mycelium, b-Thyriothecium, c- Ascus, d-Ascospores angles, loosely to closely reticulate, cells $16-32$ x 4-8 $\mu \mathrm{m}$. Appressoria few, 2-celled, unilateral to alternate, straight, curved, 9-18 $\mu \mathrm{m}$ long; stalk cells cylindrical to cuneate, 3$6 \mu \mathrm{m}$ long; head cells ovate, oblong, straight, curved, entire to slightly angular, 4-11 x 4.8-10 $\mu \mathrm{m}$. Thyriothecia scattered to grouped, initially rounded, elongated at maturity, 500-640 x 250-300 $\mu \mathrm{m}$, longitudinally fissured at the centre, margin crenate to fimbriate, fringed hyphae flexuous to crooked; asci globose to ovate, octosporous, 32-42 x 26-35 $\mu \mathrm{m}$; ascospores ovate, oblong, conglobate, brown, uniseptate, constricted at the septum, 28-35 x 12-18 $\mu \mathrm{m}$, smooth walled.

Material examined: On leaves of Salacia sp. (Hippocrataceae), Sairandhiri, Silent Valley National Park, Palakkad, Kerala, India, Dec. 13, 2003, V.B. Hosagoudar \& al $\mathrm{HClO} 46307$ (type), TBGT 1953 (isotype). This forms the first report of the genus Lembosia on the members of the family Hippocrataceae (Song \& Hosagoudar, 2003). Hence, it is described here as a new species. References

1. Song B and Hosagoudar VB (2003) A list of Lembosia species based on the literature. Guizhou Science 21, 93-101.

2. Stevens FL and Ryan MH (1939) The Microthyriaceae. Illinois Biol. Monographs 171-138. 